\title{
Papinski primat i njegovo služenje jedinstvu kršćana
}

\section{Uz 25. obljetnicu enciklike Ut unum sint}

\author{
Alan Modrić*
}

\begin{abstract}
Sažetak
U radu je pokazano koliko je prva papinska enciklika o ekumenizmu Ut unum sint, a posebice tema papinskoga primata koju dodiruje ista, važna i danas, 25 godina poslije njezina objavljivanja. Analizirana je sama enciklika, a potom su prikazani različiti dokumenti, rasprave i inicijative koji u enciklici nalaze nadahnuće i poticaj te koji nastoje doprinijeti i pomoći papinskomu primatu kako bi on i danas bio sredstvo ostvarivanja priželjkivanoga jedinstva unutar Katoličke crkve, ali i između svih kršćana.
\end{abstract}

Ključne riječi: Ut unum sint; papinski primat; jedinstvo; sinodalnost; Biskupska sinoda

\section{Uvod}

U 2020. godini, točnije 25. svibnja, navršilo se je 25 godina od objavljivanja enciklike Ut unum sint ("Da budu jedno") Ivana Pavla II., prve papinske enciklike o ekumenizmu. Tim povodom papa Franjo, u svojem pismu upućenom kardinalu Kurtu Kochu, predsjedniku Papinskoga vijeća za promicanje jedinstva kršćana, ističe činjenicu porasta uzajamnoga poznavanja i poštivanja između raznih kršćanskih crkvi i zajednica, kao i razvoja teološkoga dijaloga i različitih oblika suradnje, bilo na pastoralnoj, bilo na kulturnoj razini. Pismo završava molitvom da svi čuju poziv da s obnovljenim žarom rade na ekumenizmu i budu nadahnuti za nove proročke geste i jačanje bratske ljubavi među svim Kristovim učenicima (Franjo, 2020).

Upravo je enciklika Ut unum sint izvor nadahnuća za mnoge inicijative koje su pokrenute u prijašnjih 25 godina, iako se je očekivalo još i više, a ono što nas posebno zanima u ovom radu teološki je dijalog, ali i konkretna, praktična rješenja koja se tiču jedne "vruće" teme, koju je Ivan Pavao II. stavio na dnevni

* Dr. sc. Alan Modrić, Papinsko sveučilište Gregoriana u Rimu. Adresa: Piazza della Pilotta 4, 00187 Rim, Italija. ORCID iD: https://orcid.org/0000-0002-3455-092X.

E-adresa:modric_a@hotmail.com 
red ekumenskoga dijaloga i rasprave u svojoj enciklici: papinski primat i njegova praksa. Kao što sam naslov rada upućuje, nastojimo prikazati ovu temu polazeći od enciklike, nastavljajući putem rasprava i učenja koja su se potom razvila ponajprije u krilu Katoličke crkve, da bi završila s konkretnim rješenjima koje nudi ista, posebno u vrijeme pontifikata pape Franje. Sve to analiziramo s teološke i crkvenopravne točke gledišta, sa željom da pokažemo u kojoj mjeri je moguće pridonijeti približavanju kršćanskih crkvi, uzimajući u obzir reforme raznih pravnih tijela Katoličke crkve koje nastoji ostvariti sadašnji papa Franjo.

\section{Enciklika Ut unum sint}

\subsection{Opće značajke}

Ivan Pavao II. objavio je 25. svibnja 1995. godine prvu encikliku u 30 godina nakon Drugoga vatikanskoga koncila u kojoj je snažno naglašena tema ekumenizma i koja je objavljena mjesec dana prije službenoga posjeta Vatikanu carigradskoga patrijarha Bartolomeja. Papa ju je napisao jer je bio obuzet nadom završiti ovo tragično tisućljeće (započeto raskolom između Rima i Carigrada 1054. godine) s uzajamnim praštanjem, usuglasivši se s novim načinom upravljanja Crkvom, koji neka bude vidljivi znak jedinstva.

U uvodu dokumenta, koji se smatra programskim tekstom koji objavljuje svima, a posebno nekatoličkim crkvama, nastojanje Katoličke crkve za ekumenski dijalog, Ivan Pavao II. tvrdi da je riječ o dokumentu ponajprije pastoralnoga karaktera čiji je osnovni cilj poduprijeti nastojanja svih onih koji svojim radom žele doprinijeti kršćanskomu jedinstvu (UUS 3). Papa ne samo da poziva sve u Katoličkoj crkvi na jači ekumenski angažman, nego on sam preuzima obvezu promicanja jedinstva svih kršćana (UUS 3).

Želeći pokazati koliko je za Katoličku crkvu važan ekumenski put, Ivan Pavao II. u prvom poglavlju enciklike iznosi katolička ekumenska načela postavljena u dekretu o ekumenizmu Unitatis redintegratio Drugoga vatikanskoga koncila, te također navodi konkretna sredstva koja služe postizanju jedinstva kršćana: dija$\log$ (UUS 31-39) i praktična suradnja (UUS 40), ali iznad svega molitva koja čini dijalog plodnijim (UUS 33).

Upravo se u drugom poglavlju dokumenta govori o plodovima ekumenskoga dijaloga: obnovljeno bratstvo (UUS 41-42), solidarnost u službi čovječanstva (UUS 43-46), rast u zajedništvu (UUS 47-49). Osim toga, to poglavlje razmišlja i o odnosima s nekatoličkim crkvama Istoka i Zapada (UUS 50-76).

U trećem i posljednjem poglavlju enciklike Ivan Pavao II. postavlja pitanje koliki se put još mora prijeći do punoga jedinstva svih kršćana, naznačujući načine za nastavak i pojačanje ekumenskoga dijaloga, za usvajanje već postignutih rezultata istoga, za produbljivanje duha ekumenizma. Poglavlje završava s, po mišljenju autora, najvažnijim dijelom dokumenta, u kojem se promišlja o doprinosu Katoličke crkve u traženju jedinstva kršćana (UUS 88-96), i u kojem nailazimo na temu našega rada: pitanje papinskoga primata i njegove prakse. 
U nagovoru koji se daje na kraju enciklike zanimljivo je uočiti da je taj tekst upućen svim kršćanima, a ne samo katolicima, kao što je običaj u papinskim dokumentima.

\subsection{Služba jedinstva rimskoga biskupa (UUS 88-96)}

Potreba za jedinstvom svih kršćana, naglašena u enciklici, prizivlje nam u pamet pojam Crkve kao zajedništva, definiran na Drugom vatikanskom koncilu, koji upućuje na opću Crkvu shvaćenu kao zajedništvo sestrinskih kršćanskih crkvi (Cereti, 1995, 682).

U takvom se zajedništvu crkve međusobno obogaćuju donoseći jedna drugoj svoje vlastite svojstvene darove. Takav dar koji Katolička crkva donosi u zajedništvo kršćanskih crkvi upravo je Petrova služba rimskoga biskupa, koja je u enciklici stavljena na dnevni red kao tema ekumenskoga dijaloga i rasprave, u čemu je i najvažnija novost koju donosi dokument.

Tu je nužno istaknuti kako enciklika potvrđuje činjenicu povijesnoga razvoja kršćanskih dogmi koje tijekom vremena preuzimaju različite oblike svojega izričaja. U takvom slučaju u pojedinoj dogmi imamo ono što u njoj esencijalno pripada Božanskoj objavi, i što je neizmjenjivo, ali s druge strane postoje i izmjenjivi oblici i načini s kojima se izražavaju vjerske istine. Primjenjujući načelo povijesnosti na temu papinskoga primata, ta enciklika želi razlučiti Petrovu službu, koja se odnosi na poklad vjere, od oblika njezina obavljanja, koje pojedini autori definiraju nazivom papinstvo (Antón, 1996, 386-387).

U tom dijelu dokumenta na prvom mjestu izlaže se nekoliko dogmatskih činjenica potkrijepljenih biblijskim odlomcima. Kao prvo, služba Petrova nasljednika je od Boga ustanovljena kao trajno i vidljivo počelo i temelj jedinstva (LG 23) te je poduprta od Duha Svetoga kako bi učinila sudionicima jedinstva sve druge (UUS 88). Na taj se način pokazuje da je Petru od Krista dodijeljeno posebno poslanje i s njime poseban autoritet koji se kroz povijest nastavlja u njegovim nasljednicima. Zbog toga Ivan Pavao II. povezuje biskupsko sjedište u Rimu s osobama Petra i Pavla u toj mjeri da je rimski biskup biskup Crkve koja nosi otisak mučeništva dvojice poglavara apostolskih (UUS 90), čime se potvrđuje i duboka duhovna i teološka dimenzija Petrove službe.

U biblijskim odlomcima navedenim u tom dijelu enciklike s jedne se strane dokazuju posebna uloga i poslanje koje Petar dobiva od Krista, ali s druge strane ističe se također ljudska slabost i grješnost glave zbora apostola, koji treba prihvatiti Kristovu milost i istinski se obratiti kako bi primio u zadaću poslanje da vodi braću (UUS 91). Tu je važna i nazočnost apostola Pavla, čije duhovno iskustvo i nasljeđe treba biti usvojeno u Petrovoj službi kako bi ista imala karakter službe milosrđa koje proizlazi iz Kristova milosrđa (UUS 92-93), s obzirom na to da je i Pavlu dana posebna milost.

Nakon temeljnih dogmatskih tvrdnji i svetopisamskih odlomaka, Ivan Pavao II. nastavlja izlažući bît službe jedinstva rimskoga biskupa, koja je ukorijenjena, kako je prije rečeno, u božanskom milosrđu i povjerena, unutar Biskupskoga zbora, papi, ne zato da bi on imao u svojim rukama moć nad narodom Božjim, 
nego zato da bi ga vodio (UUS 94). Srž je njegove službe unutar Biskupskoga zbora bdjeti na način da se, zahvaljujući crkvenim pastirima, čuje istinski glas Krista Pastira u svim partikularnim crkvama. Zbog toga se u svakoj partikularnoj crkvi ostvaruje opća Crkva: sve su partikularne crkve u punom i vidljivom zajedništvu zbog toga što su njihovi pastiri u zajedništvu s Petrom, i svi zajedno su u jedinstvu s Kristom (UUS 94). Kako bi obavljao službu bdijenja i osigurao jedinstvo svih crkvi, služba rimskoga biskupa treba imati vlast i autoritet zato jer je on prvi među onima koji služe jedinstvu Crkve (UUS 94).

Petrova služba obavlja se na tri razine: liturgijsko-sakramentalnoj, pastoralnoj, koja je usmjerena na dobro cijele Crkve, i na razini čuvanja poklada vjere, a sve one idu za očuvanjem jedinstva Crkve, s obzirom na to da je papinski primat usredotočen na to jedinstvo, koje je ponajprije jedinstvo vjere. U svjetlu jedinstva promatraju se i vlast i autoritet, bez kojih bi obavljanje Petrove službe bilo beskorisno (UUS 94).

Takvu službu jedinstva, koja se, među ostalim, mora promatrati i u sklopu zajedništva Biskupskoga zbora, Ivan Pavao II. stavlja na dnevni red ekumenskoga dijaloga, priznajući svoju posebnu odgovornost za jedinstvo svih kršćana i pozivajući sve kršćanske pastire i teologe da mu pomognu u iznalaženju novih oblika obavljanja službe jedinstva rimskoga biskupa, koji, iako trebaju sačuvati ono što je dogmatski esencijalno u toj službi, ipak, s druge strane, moraju se otvoriti i novim situacijama (UUS 95-96).

Nakon učenja o bîti službe jedinstva rimskoga biskupa, potvrđuje se načelo zajedništva drugih partikularnih crkvi s rimskom partikularnom crkvom, i njihovih biskupa s rimskim biskupom, što je bitni uvjet punoga i vidljivoga crkvenoga zajedništva (UUS 97). Takvo zajedništvo ima potrebu za jednim vidljivim izričajem u službi u kojoj bi se svi biskupi vidjeli ujedinjeni i svi bi vjernici našli potvrdu svoje vjere (UUS 97). Takva služba bila bi služba apostola Petra, koji je u Djelima apostolskim prikazan kao glasnogovornik apostola i služitelj jedinstva kršćanske zajednice, i zbog toga iskazuje poštovanje prema vlasti apostola Jakova kao glave crkve u Jeruzalemu (UUS 97). Neki autori smatraju da Ivan Pavao II. tom službom glasnogovornika, koji ne umanjuje vlast drugih biskupa u njihovim mjesnim crkvama, nudi jedan od mogućih oblika obavljanja Petrove službe u ekumenskim odnosima (Filippi, 2004, 71).

\section{Teološki odgovor na encikliku}

\subsection{U okviru Katoličke crkve}

U ovom dijelu rada cilj je prikazati doprinos Katoličke crkve raspravi o papinskom primatu koja se odvijala nakon enciklike Ut unum sint sve do početka pontifikata pape Franje, čije učiteljstvo ostavljamo za sljedeću točku u radu. Ovdje je pažnja usredotočena na najvažnije elemente koje je ponudila Katolička crkva toj raspravi u rečenom razdoblju, a koji su ponajprije rezultat rada dvaju crkvenih tijela: Kongregacije za nauk vjere i Biskupske sinode. 
U Rimu je od 2. do 4. prosinca 1996. godine organiziran od strane Kongregacije za nauk vjere teološki simpozij na temu Primat Petrova nasljednika, koji je za cilj imao proučiti nepobitne elemente nauka o papinskom primatu vodeći računa o razlučivanju supstancije Petrove službe, koja je božanskoga ustanovljenja, od povijesnih oblika izvršavanja te službe. Simpozij je imao tri glavne teme: a) dogmatski smisao primata Petrova nasljednika; b) odnos između primata i episkopata; c) karakter i svrha primatskih intervencija rimskoga biskupa (Ratzinger, 1998, 17).

Da ne ulazimo previše u detalje, ovdje je zanimljivo, u okviru teme ovoga članka, istaknuti nekoliko činjenica koje su evidentirane tijekom rada simpozija: a) primat je ukorijenjen u osobi apostola Petra i njegovih nasljednika kako bi oni služili jedinstvu biskupskoga zbora i cijele Crkve; b) nužno je da takav osobni primat ima potrebnu slobodu za učinkovito promicanje jedinstva Crkve bez potrebe traženja odobrenja drugih biskupa (Henn, 1998, 272); c) rimski je biskup onaj koji daje glas zajedništvu svih vjernika bilo izravno, bilo tako da je u službi episkopata koji je, sa svoje strane, u službi vjernika (Buckley, 1998, 315).

U svjetlu rezultata simpozija Kongregacija za nauk vjere izdala je 1998. godine dokument naslovljen Primat Petrova nasljednika u otajstvu Crkve, u kojem je dala vlastiti doprinos teološkoj raspravi o papinskom primatu iznoseći bitna i nužna načela katoličkoga nauka na tu temu.

U prvom dijelu dokumenta ističe se da je svrha primata ostvarivanje i služenje jedinstva vjere i zajedništva jer je rimski prvosvećenik, kao Petrov nasljednik, trajno i vidljivo počelo i temelj jedinstva biskupa i svih vjernika (LG 23), zbog čega ima posebnu milost kako bi služio takvomu jedinstvu vjere i zajedništva (Kongregacija, 1998, br. 4).

Rimski biskup ima, kao i svi drugi biskupi koji su članovi biskupskoga zbora, skrb ne samo za vlastitu partikularnu crkvu, nego i za sve druge partikularne crkve. Kada se uzme u obzir taj element njegova primata, kao i činjenica njegove vlasti, koja je izravna nad svim partikularnim crkvama, tada se uviđa da primat nije izvanjska stvarnost u odnosu na partikularne crkve, nego čini bitan dio njihove nutarnje strukture, i zbog toga nosi u sebi otvorenost za služenje crkvenomu jedinstvu (Kongregacija, 1998, br. 6).

U svojem drugom dijelu dokument se bavi obavljanjem primata i oblicima toga obavljanja. To obavljanje ima dvije temeljne značajke: a) primat se obavlja u službi jedinstva episkopata i svih vjernika; b) vodeći računa o biskupskom karakteru primata, on se odražava u trostrukoj funkciji - učiteljskoj, upravljačkoj i sakramentalnoj. U pogledu upravljačke funkcije, dokument ističe činjenicu da rimski prvosvećenik, iako ne treba nikomu pravno odgovarati za obavljanje primata, ipak nema apsolutističku vlast, jer slušanje onoga što imaju reći mjesne crkve znak je službe jedinstva i posljedica jedinstva biskupskoga zbora i osjećaja vjere (sensus fidei) cjelokupnoga Božjega naroda (Kongregacija, 1998, br. 10).

Godine 2001. održana je deseta opća redovita skupština Biskupske sinode, koja je raspravljala o ulozi biskupa kao služitelja Evanđelja Isusa Krista, i u sklopu toga dotaknula je temu papinskoga primata i njegova odnosa s episkopatom. 
Rezultati rada Biskupske sinode posebno se zrcale u apostolskoj pobudnici $\mathrm{Pa}$ stores gregis ("Pastiri stada”) Ivana Pavla II., objavljenoj 2003. godine.

Pobudnica ponajprije tvrdi da je svaki pojedini biskup uvijek povezan s drugim biskupima i s Petrovim nasljednikom, te iz takvoga kolegijalnoga jedinstva, za koje Drugi vatikanski koncil koristi izraz affectus collegialis ("kolegijalni osjecaj”), proizlazi skrb biskupa za druge partikularne crkve i za univerzalnu Crkvu (PG 8). Takva skrb iskazuje se na različite načine, a u naše vrijeme posebno putem Biskupske sinode, što će biti jasnije kada budemo razmatrali učiteljstvo pape Franje.

Povezanost svakoga biskupa s Petrovim nasljednikom i s drugim biskupima vrijedi također i za papu, koji je i kao poglavar Katoličke crkve, i kao dijecezanski biskup Rima, uvijek povezan sa svim drugim biskupima te u njima nalazi oslonac i podršku za obavljanje Petrove službe, kao što i svaki biskup na temelju kolegijalnoga jedinstva (affectus collegialis) nalazi oslonac i podršku u papi i Biskupskom zboru za obavljanje svoje pastirske službe u partikularnoj crkvi.

Zbog svega toga Pastores gregis tvrdi da, kao što se biskup pri obavljanju svoje uprave u biskupiji uvijek nalazi u hijerarhijskom zajedništvu s rimskim prvosvećenikom i Biskupskim zborom, tako i rimski prvosvećenik u svojoj službi vrhovnoga pastira Crkve djeluje uvijek povezan sa svim drugim biskupima, štoviše čak i s cijelom Crkvom (PG 56). I na taj način papa ostvaruje službu jedinstva, toliko istaknutu u enciklici Ut unum sint.

\subsection{U okviru ekumenskih odnosa}

S obzirom na to da je za Katoličku crkvu u Hrvatskoj ponajprije važan odnos s pravoslavnom braćom, ovdje ćemo se ograničiti na to da vidimo kako se razvijao teološki dijalog između tih dviju sestrinskih crkvi u svjetlu zahtjeva koje je pred njih stavila enciklika Ut unum sint. Za taj dijalog smatramo posebno bitnim onaj njegov dio koji se je odvijao u krilu Međunarodne mješovite komisije za teološki dijalog između Katoličke i Pravoslavne crkve.

U tom smislu osobito su bitna dva dokumenta komisije: Crkvene i kanonske posljedice sakramentalne naravi Crkve: Crkveno zajedništvo, koncilijarnost $i$ autoritet, tzv. Ravenski dokument (Međunarodna mješovita komisija, 2007) i Sinodalnost i primat u prvom tisućljeću: Na putu zajedničkog razumijevanja u službi jedinstva Crkve, tzv. dokument iz Chietija (Međunarodna mješovita komisija, 2016).

Oba dokumenta ističu pojam sinodalnosti kao temeljne kvalitete Crkve kao cjeline, s kojim se ponajprije označuje skup biskupa koji ostvaruju posebnu zadaću, ali u širem smislu odnosi se na sudjelovanje svih vjernika u životu i poslanju Crkve (Međunarodna mješovita komisija, 2007, 709; 2016, 576-577). S druge strane, pojam primata odnosi se na ulogu prvoga (primus, protos). Crkvena tradicija nedvojbeno svjedoči da je biskup unutar sinodalnoga života Crkve na različitim razinama uvijek bio priznat kao "prvi". Isus Krist povezuje tu ulogu "prvoga" sa "služenjem" (diakonia). U zaključku dokumenta iz Chietija ističe se da je za vrijeme prvoga tisućljeća Crkva na Istoku i Zapadu bila ujedinjena po tom što je čuvala apostolsku vjeru, održavala apostolsku sukcesiju biskupa, razvijala struk- 
ture sinodalnosti u neodjeljivoj povezanosti s primatom te što je razumijevala autoritet kao službu (diakonia) ljubavi (Međunarodna mješovita komisija, 2016, 579; Ikić, 2017, 74).

Sinodalna dimenzija Crkve ostvaruje se na tri razine crkvenoga zajedništva: lokalnoj, regionalnoj i općoj. Na lokalnoj razini biskup je protos mjesne crkve. Regionalna razina objedinjuje više biskupa koji su između sebe birali glavnoga (kephalé), koji je na regionalnoj razini bio prvi (protos), kako je određivao 34. kanon Apostolske konstitucije iz 4. stoljeća. Taj kanon temelj je sinodalnoga poretka na kojem počiva struktura pravoslavnih crkava i utvrđuje da izabrani protos regije nije ništa činio bez pristanka drugih biskupa regije, a drugi biskupi regije nisu ništa činili bez njegova pristanka (Međunarodna mješovita komisija, 2007, 712; 2016, 578). Treća je ona opća razina na kojoj su definicije vjere i nauka donosili opći koncili, čije odredbe vrijede za sve mjesne i regionalne crkve.

U dokumentima Komisije priznaje se da je u prvom tisućljeću kršćanstva jedinstvo Crkve bilo održavano, osim u koncilima, također pomoću bratskih odnosa između samih biskupa, između biskupa i njihovih regionalnih "prvih" (protoi), i između samih "prvih" u kanonskom poretku (taxis). Takvi odnosi temeljili su se na savjetovanjima, pismima i prizivima glavnim biskupskim stolicama (Rim, Konstantinopol, Aleksandrija, Antiohija i Jeruzalem), posebno onoj rimskoj (Međunarodna mješovita komisija, 2007, 714; 2016, 578-579).

Na objema stranama teolozi se slažu da je na općoj crkvenoj razini Rimska crkva presjedala u ljubavi, zbog čega je rimski biskup imao ulogu protosa među regionalnim patrijarsima, ali teolozi se do sada nisu usuglasili što je to konkretno značilo (Međunarodna mješovita komisija, 2007, 714).

Tu je važno naznačiti kako Međunarodna mješovita komisija trenutačno radi na novom dokumentu koji bi se bavio temom primata i sinodalnosti u drugom tisućljeću i danas. Ostaje nada da će se novim dokumentom nastaviti put približavanja sestrinskih crkvi u pogledu teme papinskoga primata i njezina služenja jedinstvu kršćana.

\section{Važnost i primjena enciklike Ut unum sint tijekom pontifikata pape Franje}

\subsection{U prvim godinama pontifikata}

Već u svojem prvom dokumentu, apostolskoj pobudnici Evangelii gaudium ("Radost evanđelja"), sadašnji rimski biskup daje do znanja koliko su enciklika njegova predšasnika Ivana Pavla II. i poziv na reforme koji upućuje isti nazočni i bitni i u 21. stoljeću, kada utvrđuje da on osobno treba ostati otvoren za prijedloge koji mogu pomoći da se Petrova služba obavlja što vjernije značenju koje joj je Isus Krist htio dati i sadašnjim potrebama evangelizacije (EG 32). Pri tom papa Franjo izričito navodi poziv Ivana Pavla II. da mu se pomogne kako bi pronašao »takav oblik vršenja primata, koji bi se otvorio novoj situaciji, ne odričući se nikako bitnoga u tom poslanju « (UUS 95). Nažalost, kako sam papa kaže u pobudnici, na tom se je polju još uvijek malo napredovalo te podcrtava potrebu 
papinstva i središnjih struktura opće Crkve za slušanjem poziva na pastoralnu preobrazbu (EG 32).

Kao bitan doprinos ostvarenju zahtjeva enciklike Ut unum sint Franjo tijekom svoga pontifikata stavlja naglasak na sinodalnost Crkve. Da bismo shvatili značenje i smisao te ekleziološke vizije sadašnjega rimskoga biskupa, potrebno je analizirati dva dokumenta njegova učiteljstva u kojima objašnjava što znači sinodalnost za današnju Crkvu te u kojima možemo uočiti krajnju točku do koje je došla ista u interpretaciji i primjeni enciklike Ivana Pavla II. 25 godina poslije njezina objavljivanja.

Prvi je od tih dokumenata govor pape Franje održan prigodom obilježavanja pedesete obljetnice Biskupske sinode, u kojem predlaže hod sinodalnosti kao programsku obvezu za cijelu Crkvu u trećem tisućljeću. Na prvom mjestu istaknut je sensus fidei ("osjećaj vjere") Božjega naroda kao temeljni kriterij vjerodostojnosti takvoga hoda, koji sprječava da se strogo odvoji hijerarhija Crkve od vjernika, jer i narod posjeduje vlastito osjetilo za razlučivanje novih puteva koje Gospodin otkriva Crkvi (Franjo, 2015, 1139-1140).

Sinodalna Crkva je crkva uzajamnoga slušanja svih sastavnica života Crkve: vjerničkoga naroda, Zbora biskupa, biskupa Rima. U tom se očituje i smjer sinodalnoga hoda, jer on započinje najprije slušanjem Božjega naroda, potom se nastavlja slušajući pastire kao vjerodostojne čuvare, tumače i svjedoke vjere čitave Crkve, te na koncu doseže svoj vrhunac u slušanju rimskoga biskupa, kao vrhovnoga svjedoka vjere čitave Crkve, koji se ipak ne nalazi sam iznad Crkve, nego unutar nje kao kršteni među krštenima, a unutar Zbora biskupa kao biskup među biskupima, pozvan istovremeno — kao nasljednik apostola Petra — voditi crkvu Rima, koja predsjeda u ljubavi svim crkvama (Franjo, 2015, 1141).

U svojem govoru papa Franjo iznosi neke elemente koje smo susreli i u dokumentima Međunarodne mješovite komisije za teološki dijalog između Katoličke i Pravoslavne crkve, kao što su tri razine crkvenoga zajedništva na kojima se ostvaruje sinodalnost Crkve: lokalna, regionalna i opća. Na lokalnoj razini sinodalnost se očituje u partikularnim crkvama i njihovim tijelima, kao što su biskupijska sinoda, prezbitersko vijeće, zbor savjetnika, kanonički kaptol i pastoralno vijeće, ukoliko su povezani s vjernicima i njihovim konkretnim i svagdašnjim poteškoćama. Na regionalnoj razini sinodalnost dolazi do izražaja u skupštinama partikularnih crkava, kao što su posebice biskupske konferencije, koje, po Franjinu mišljenju, trebaju još više doprinijeti rastu kolegijalnoga zajedništva među biskupima (Franjo, 2015, 1143). Na kraju, na općoj razini sinodalnost se ostvaruje ponajprije u krilu Biskupske sinode, čije značenje u primjeni zahtjeva enciklike Ut unum sint nastojimo analizirati u sljedećoj točki rada.

\subsection{Apostolska konstitucija Episcopalis communio}

Apostolska konstitucija o Biskupskoj sinodi Episcopalis communio (15. rujna 2018) može se smatrati najkonkretnijom primjenom enciklike Ut unum sint tijekom sadašnjega pontifikata jer, provodeći reformu Biskupske sinode, što je, u biti, njezina primarna zadaća, nastoji još više ostvariti dijalog i suradnju između 
rimskoga biskupa i ostale njegove braće u biskupstvu, ali i povezanost onoga prvoga s cijelom Crkvom. Takav cilj nastoji se ostvariti ne samo na temelju kolegijalnoga duha koji postoji među svim biskupima, nego i na temelju sinodalnosti Crkve, gdje na određeni način i u određenom stupnju cijeli Božji puk slijedi sinodalni hod kako bi se još više ostvarilo ono što je, u biti, već sadržano u Drugom vatikanskome koncilu, a to je univerzalnost Crkve i duboka unutarnja povezanost svih njezinih sastavnica (LG 13), a još konkretnije i jasnije izraženo u Zakoniku kanonskoga prava, koji kaže da »Rimski prvosvećenik, u vršenju službe vrhovnog pastira Crkve, uvijek je zajedništvom povezan s ostalim biskupima, dapače i sa svom Crkvom « (CIC kan. 333 §2). ${ }^{1}$

Takvo zajedništvo rimskoga prvosvećenika i cijele Crkve u kojem on obavlja svoju službu vrhovnoga pastira kao ponajprije službu jedinstva između svih drugih pastira i svih vjernika, a koja je prikazana u različitim dokumentima analiziranim u ovom radu, konstitucija Episcopalis communio nastoji ostvariti polazeći od činjenice osjećaja vjere (sensus fidei), koji posjeduje cijeli narod Božji. Takav osjećaj vjere omogućuje jedinstvo u njezinu ispovijedanju, zahvaljujući kojemu Crkva »ne može pogriješiti u vjerovanju« (LG 12). Konstitucija percipira pastire Crkve (biskupe) istovremeno i kao učitelje, kada urešeni posebnom pomoći Duha Svetoga navješćuju vjernicima evanđelje, i kao učenike, kada, svjesni da je Duh darovan svim vjernicima, osluškuju glas Krista koji govori kroz cijeli vjernički puk čineći ga nezabludivim u vjerovanju (EC 5). Uglavnom, pastiri bi trebali imati uši otvorene za "glas ovaca" kroz ona crkveno pravna tijela koja imaju zadatak savjetovati pastire, promičući iskren i konstruktivan dijalog (EC 5).

Jedno od takvih tijela upravo je Biskupska sinoda, koja, iako sačinjava biskupsko tijelo, nije odvojena od ostalih vjernika, nego je prikladno sredstvo da se čuje glas cijeloga Božjega naroda preko biskupa te da taj glas dospije do rimskoga biskupa, jer zadaća je toga tijela savjetovati i pomoći rimskomu prvosvećeniku u obavljanju njegove službe (CIC kann. 334 i 342), a u određenim slučajevima i donositi odluke, ako joj je takvu vlast dao papa (CIC kan. 343). Na taj način dolazi i do ostvarenja službe jedinstva koju obavlja papa.

Na takvim teološkim temeljima konstitucija provodi reformu Biskupske sinode s ciljem da se ostvari ideal što veće povezanosti između vrhovnoga pastira Crkve i Božjeg naroda, kako je to zacrtao Drugi vatikanski koncil, a u djelo nastojali provesti pape od Pavla VI. do Franje. Reforma sinode sastoji se ponajprije u tom da se strukturira jedan detaljni postupak u kojem bi bile uključene sve partikularne crkve u sinodalnom hodu. Za tu svrhu konstitucija u svojem normativnom dijelu predviđa tri susljedne faze odvijanja svake sinodske skupštine: ${ }^{2}$ pripremna faza, faza održavanja i faza provedbe.

1 Isticanje je autora rada. Taj kanon citira i prethodno spomenuta pobudnica Pastores gregis u broju 56.

2 Postoji tri tipa sinodskih skupština: a) opća redovita, koja obrađuje teme koje se odnose na opće dobro Crkve; b) opća izvanredna, gdje se raspravlja o temama koje se tiču općega dobra Crkve i trebaju biti hitno razmotrene; c) posebna, gdje se raspravlja o temama koje se uglavnom odnose na jedno ili više posebnih geografskih područja (EC 1). 
Svrha pripremne faze, koja počinje kada rimski prvosvećenik sazove sinodsku skupštinu, savjetovanje je s Božjim narodom o temi sinodske skupštine (EC 5 §). Takvo savjetovanje provodi se s različitim sastavnicama Crkve, kao što su partikularne crkve, unije, savezi i konferencije ustanova posvećenoga života i družbi apostolskoga života, vjernička društva, vjernici pojedinačno, uredi Rimske kurije, visoka crkvena učilišta (EC 6 i 9). Svaka od tih sastavnica može poslati Generalnomu tajništvu sinode sintezu svojih doprinosa u pripremnoj fazi. Za svrhu savjetovanja u pripremnoj fazi može se održati i predsinodski sastanak (EC 8).

Poslije pripremne faze slijedi faza održavanja sinodske skupštine, koja ima za cilj raspravu o zadanoj temi skupštine i izradu završnoga dokumenta sinode. Rasprava se odvija među biskupima koji sudjeluju na skupštini na temelju slušanja i razlučivanja glasa Božjega naroda, koji se je očitovao tijekom pripremne faze i koji na kraju dolazi do rimskoga biskupa, koji je pozvan izjasniti se o zadanoj temi skupštine, ne polazeći isključivo od svojih osobnih uvjerenja, nego kao vrhovni svjedok vjere cjelokupne Crkve (Franjo, 2015, 1140-1141).

Ključan je trenutak faze održavanja sinodske skupštine izrada i odobrenje završnoga dokumenta, koji se, nakon što su ga odobrili članovi skupštine, predaje rimskomu prvosvećeniku i koji, ako ga papa odobri, postaje dijelom njegova redovitoga učiteljstva (EC 18).

$\mathrm{Na}$ kraju dolazi faza provedbe sinodske skupštine, gdje se dijecezanski ili eparhijski biskupi, kao i biskupske konferencije i sinode biskupa istočnih katoličkih crkvi, brinu uz pomoć tijela sudioništva predviđenih pravom za prihvaćanje i provedbu zaključaka skupštine na lokalnoj i regionalnoj razini (EC 19). U toj fazi posebno je važna zadaća Generalnoga tajništva Biskupske sinode, koje za tu svrhu može osnovati i posebno povjerenstvo za provedbu (EC 21).

Vidjeli smo u analiziranim normama konstitucije kako ona nastoji provesti u djelo to što je zaželio i zazvao Ivan Pavao II. u svojoj enciklici objavljenoj 23 godine prije konstitucije. Kako bi još više doprinijela ekumenskomu približavanju, konstitucija predviđa mogućnost da rimski prvosvećenik, zbog razloga ekumenske naravi i ako to drži prikladnim, sazove sinodsku skupštinu i prema oblicima drugačijim od onih već propisanih u konstituciji (EC 1). U biti, papa Franjo ističe svoje uvjerenje da Biskupska sinoda, potičući preobrazbu papinstva, može na svoj način pridonijeti ponovnoj uspostavi jedinstva među svim kršćanima u skladu s Gospodinovom voljom »da svi budu jedno« (EC 10).

\section{Zaključak}

Enciklika Ut unum sint jedan je od onih crkvenih i papinskih dokumenata koji ostaju kroz dugo vremena izvor nadahnuća, nadi, čežnja, ali isto tako izaziva nemir i pitanja poput: Nije li se već prije trebalo početi s onim procesima na koje enciklika toliko poziva ili zašto je do sada učinjeno, barem po mišljenju nekih, toliko malo ili zašto su ti procesi toliko spori i dugotrajni ili čak i nedovoljno konkretni? Sve to ukazuje na nepobitnu činjenicu koliko je ta enciklika važna, a još više koliko je važno na konkretnom polju primijeniti one reforme na koje poziva 
njezin autor Ivan Pavao II., a koje su potrebne kako za život same Katoličke crkve, tako i za jedinstvo sve kršćanske braće i sestara.

Mogli smo uočiti da ipak, unatoč poteškoćama ili sporosti, reforme u pogledu papinskoga primata, ne dirajući u ono esencijalno što se ne može izmijeniti, ali prilagođavajući oblike obavljanja primata novim situacijama vremena u kojem živimo, ne ostaju samo na razini teoretske rasprave, nego sve se više ostvaruju u konkretnim rješenjima. U tom pogledu možemo s pravom ustvrditi da se, unatoč svemu, korak po korak, pa makar to bili ponekad i puževi koraci, približavamo sve većemu jedinstvu vjernika, kako unutar Katoličke crkve, tako i unutar cjelokupnoga kršćanstva. Nikada se ne smijemo umoriti u traženju novih i boljih rješenja, jer uvijek može i treba biti bolje, a sve to sa željom da jednoga dana konačno budemo jedno.

\section{Literatura}

Antón, Ángel (1998). "Ministerio Petrino" y/o "Papato" en el diàlogo con las otras Iglesias cristianas: algunos puntos de convergencia y divergencia. U: Vincenzo Mosca (ur.), Il primato del successore di Pietro (str. 386-453). Roma: Libreria editrice vaticana.

Buckley, Michael John (1998). "Perpetuum Utriusque Unitatis Principium ac visibile Fundamentum". The Primacy and the Episcopate: Towards a doctrinal Synthesis. U: Vincenzo Mosca (ur.), Il primato del successore di Pietro (str. 281-339). Roma: Libreria editrice vaticana.

Cereti, Giovanni (1995). L'enciclica "Ut unum sint". Rassegna di teologia, 36, 679-697.

CIC. Codex Iuris Canonici. Ivan Pavao II., Zakonik kanonskoga prava. Zagreb: Glas Koncila, 1996.

EC. Episcopalis communio. (15. rujna 2018.) Franjo, Episcopalis communio: Apostolska konstitucija o Biskupskoj sinodi: Uputa o slavljenju sinodskih skupština i o radu Generalnog tajništva Biskupske sinode. Zagreb: Kršćanska sadašnjost, 2019.

EG. Evangelii gaudium. (24. studenoga 2013.) Franjo, Evangelii gaudium: Radost evandelja: Apostolska pobudnica biskupima, prezbiterima i đakonima, posvećenim osobama $i$ svim vjernicima laicima o naviještanju evanđelja u današnjem svijetu. Zagreb: Kršćanska sadašnjost, 2015.

Filippi, Nicola (2004). Essenza e forma di esercizio del ministero petrino: Il magistero di Giovanni Paolo II e la riflessione ecclesiologica. Roma: Pontificia Università Gregoriana.

Franjo (2015). Occasione L anniversariae memoriae ab inita Synodo Episcoporum. Acta Apostolicae Sedis, 107(11), 1138-1144.

Franjo (2020). Lettera del Santo Padre Francesco al cardinale Kurt Koch in occasione del $25^{\circ}$ dell'enciclica Ut unum sint. Vatica. va. URL: https://w2.vatican.va/content/ francesco/it/letters/2020/documents/papa-francesco_20200524_lettera-card-koch. html (10.6.2020.)

Henn, William (1998). Historical-theological Synthesis of the Relation between Primacy and Episcopacy during the Second Millennium. U: Vincenzo Mosca (ur.), Il primato del Successore di Pietro (str. 222-273). Roma: Libreria editrice vaticana.

Ikić, Niko (2017). Primat u sinodalnosti — sinodalnost u primatu: Refleksije na Katoličko-pravoslavni dijalog. Riječki teološki časopis, 25, 59-80.

Kongregacija (1998). Kongregacija za nauk vjere, Il primato del successore di Pietro nel mistero della Chiesa. L'Osservatore Romano, (31. listopada), 7. 
LG. Lumen gentium. (21. studenoga 1964.) Drugi vatikanski koncil, Dogmatska konstitucija Lumen genitum o Crkvi. U: Josip Turčinović (ur.), II vatikanski koncil: Dokumenti: Latinski i hrvatski (str. 91-204). Zagreb: Kršćanska sadašnjost, ${ }^{1} 1970$.

Međunarodna mješovita komisija (2007). Međunarodna mješovita komisija za teološki dijalog između Katoličke i Pravoslavne Crkve, Il documento di Ravenna. Il RegnoDocumenti, 52, 708-714.

Međunarodna mješovita komisija (2016). Međunarodna mješovita komisija za teološki dijalog između Katoličke i Pravoslavne Crkve, Sinodalità e Primato nel Primo Millennio. Verso una comune comprensione nel servizio all'unità della Chiesa. Il Regno-Documenti, 61, 576-579.

PG. Pastores gregis. (16. listopada 2003.) Ivan Pavao II., Pastores gregis: Pastiri stada: Postsinodska apostolska pobudnica o biskupu služitelju evanđelja Isusa Krista za nadu svijeta. Zagreb: Kršćanska sadašnjost, 2003.

Ratzinger, Joseph (1998). Discorso in apertura del Simposio. U: Vincenzo Mosca (ur.), Il primato del successore di Pietro (str. 15-19). Roma: Libreria editrice vaticana.

UUS. Ut unum sint. (25. svibnja 1995.) Ivan Pavao II., Ut unum sint: Da budu jedno: Enciklika o ekumenskom nastojanju: Orientale lumen: Svjetlo istoka: Apostolsko pismo biskupima, svećenicima i vjernicima prigodom stogodišnjice apostolskog pisma "Orientalium dignitas" pape Lava XIII. Zagreb: Kršćanska sadašnjost, 1995.

On the Occasion of the 25th Anniversary of the Encyclical Ut unum sint

Papal Primacy and its Service to the Unity of Christians

Alan Modrić*

\section{Summary}

The intent of this article is to demonstrate the significance of the ecumenical encyclical Ut unum sint, and especially that of its most important topic namely, the papal primacy in ecumenical relations, even today, twenty-five years after its publication. Firstly, the article analyses the encyclical's emphasis on the Bishop of Rome and his ministry of unity, both in the Catholic Church and among all Christians. The author includes also an examination of various Church documents which find their inspiration in the encyclical and which discuss the papal primacy in the light of the invitation of John Paul II to "find a way of exercising the primacy which, while in no way renouncing what is essential to its mission, is nonetheless open to a new situation» (UUS 95). Finally, the article highlights the fact that there is not only a theoretical discussion on this papal request, but also concrete juridical regulations and solutions which can bring it to fruition, especially during the pontificate of Pope Francis whose apostolic constitution Episcopalis communio on the reform of the Synod of Bishops can be considered an endpoint of sorts in the search for new ways of exercising the primacy.

Key words: Ut unum sint; papal primacy; unity; synodality; synod of bishops

* Alan Modrić, Ph.D., Pontifical Gregorian University. Address: Piazza della Pilotta 4, 00187 Rome, Italy. E-mail: modric_a@hotmail.com 